Article

\title{
Variability in the Wettability and Water Storage Capacity of Common Oak Leaves (Quercus robur L.)
}

\author{
Anna Klamerus-Iwan * (ID) and Wojciech Witek * \\ Faculty of Forestry, Department of Forest Engineering, University of Agriculture in Krakow, Al. 29 Listopada 46, \\ 31-425 Krakow, Poland \\ * Correspondence: a.klamerus-iwan@ur.krakow.pl (A.K.-I.); w.witek@ur.krakow.pl (W.W.); \\ Tel.: +48-126-625-356 (A.K.-I.); +48-12-662-5356 (W.W.)
}

Received: 25 April 2018; Accepted: 24 May 2018; Published: 27 May 2018

\begin{abstract}
The canopy water storage capacity and wettability of the plant material are significantly dependent on the condition of the leaf surface. The aim of the present research was an analysis of the influence of infection with oak powdery mildew, seasonal changes occurring on leaves and factors related to location on the surface of leaves and their hydrological properties. This study performed a series of experiments connecting the direct spraying of tree branches with simulated rainfall under laboratory conditions; an analysis of the content of aromatic hydrocarbons in leaves with the use of the chromatograph; and measurements of the angles of adherence of raindrops to the leaf surface. Degree of wettability was determined and, additionally, photographs were taken with a scanning electron microscope. The experiments were performed on common oak (Quercus robur L.) both in the city and in the forest, on two dates: in May and September. All series of measurements were done on healthy leaves and on leaves covered with oak powdery mildew (Microsphaera alphitoides Griff. et Maubl.) to various degrees. Oak powdery mildew has the largest influence on the canopy water storage capacity and on hydrophobicity. In September, the leaves retained an average of $7.2 \mathrm{~g} / \mathrm{g}$ more water than in May; and, in the leaves from the city, the canopy water storage capacity was $3.1 \mathrm{~g} / \mathrm{g}$ higher. A decreasing angle of inclination of raindrops to leaves testified to growing wettability and increased the amount of water retained in tree crowns. An additional analysis of SEM photographs points to a dependency of the canopy water storage capacity on the condition of the surface of leaves.
\end{abstract}

Keywords: ecohydrology; interception; mildew; oak powdery; pollution; seasonal changes

\section{Introduction}

In ecohydrology, the amount of rainwater retained on the tree leaves and woody surfaces is the phenomenon called canopy water storage capacity (S) [1]. The phenomenon plays a very important role in the water balance [2,3]. The possibility that water interception amounts to $10-50 \%$ of the total rainfall was indicated by Crockford and Richardson [4].

In the light of physical knowledge of the processes of wetting and retaining water on the surface of various bodies, and not just the plant material $[5,6]$, it should be assumed that the wetting and entrainment of water on plant surfaces (and other terrestrial surfaces) during storms is influenced by leaf surface traits [7-11] and rainfall characteristics [12]. Field studies have estimated that the crowns of deciduous and coniferous trees are saturated by $0.5-8.2 \mathrm{~mm}$ of rainfall $[2,13,14]$. In this context, it may be repeated after Keim [15] that the crown's ability to retain water can be treated as a constant value only for a single rain while subsequent rains can modulate that ability. The residence time of precipitation in the different storage components varies significantly $[16,17]$.

Due to the above statements, it is very important to determine which factors may affect an increase in the amount of water retained in the crown and which factors strongly reduce it. 
Crockford and Richardson [4] considered the species-related water storage capacity of the crown to be a key feature affecting the amount of interception. However, e.g., in studies by Bryant et al. [18], after analyzing the losses for interception in stands composed of different species, the conclusion was drawn that those losses are very similar.

Significant seasonal and interspecific variability in $S$ has been observed [19-21]. Perhaps it is also related to seasonal changes in the temperature of rainwater [22].

Factors which determine the condition of the plant surface and are important for interception include the degree of contamination of that surface and changes during the growing season $[19,23]$. The amount of pollution retained is a species-related characteristic [24]. Some species, including oak, are used for biomonitoring of air pollution [25]. The increase of air pollution with tar substances rich in polycyclic aromatic hydrocarbons is an important problem because they are ubiquitous in the environment [26] and thus they are difficult to disregard in hydrological research [27]. The question of the impact of infections, diseases or air pollution related to the location of sample collection does not seem to have been investigated. An important aspect of the present study was to examine whether the location of the tree from which samples were obtained had an influence on the canopy water storage capacity.

There is a plant division system according to the Aryal and Neuner plant classification [28] from the least hydrophilic to the superhydrophilic ones. The classification is based on the size of the angle at which a drop of water adheres to the leaf. Koch and Barthlott [21] and Shujie et al., [29] combined the effectiveness of wetting with such elements as leaf hairs. Undoubtedly, the amount of waxes in the cuticle also has a large impact on the amount of water retained and on the contact angle of the raindrop to the leaf [30]. Wettability is also related to the species and the leaf surface condition [31]. Among the thoroughly analyzed effects are the lotus effect [19] and the self-cleaning of leaves [32].

Superhydrophobicity provides protection against plant pathogens such as fungi and bacteria because an infection is limited by a lack of water and humidity [33]. Moisture and warm temperatures are exactly what some oak diseases, such as powdery mildew (Microsphaera alphitoides Griff. et Maubl), need for the development of conidia [34].

Severely infected leaves and shoots undergo gradual dying, visible as browning and blackening, which leads to their premature falling. Later, among areas of white coating (conidia clusters), there often appear black spheres (perithecia) with a diameter of about $0.1 \mathrm{~mm}$, which can be very numerous [35]. Such a coating has a hydrophilic character. This leads to a question whether leaves infected with this fungus have a different canopy water storage capacity. This question has significant ecohydrological implications because increased $S$ and wettability of infected oak leaves may create conditions that enable further development of the disease. One of the aims of the present study is to test whether the oak powdery mildew cover on leaves increases $S$ and changes wettability.

Canopy phenology introduces temporal variability in the patterning and traits of leaf surfaces that, in turn, affect rainfall partitioning into throughfall, stemflow, and interception [36-38]. Based on this, another aim of the study was to test whether, under the impact of the leaf cover with oak powdery mildew and with pollution related to location, seasonal changes still have a significant influence on $\mathrm{S}$ and contact angles.

These issues are important in the context of research not only on urbanized basins, where the presence of pollution is inevitable, but also in research on forest areas, where diseases of the leaves are frequent. Revealing these changes against the background of the naturally changing seasonal properties of leaves presents an innovative study of the problem.

In summary, the aim of the present research was the collection of data for an analysis of the impact of (Microsphaera alphitoides Griff. et Maubl), seasonal changes and the degree of pollution associated with location on the leaf-water contact angle and S. The aim was to determine whether hydrophobic pollution increases the hydrophobicity of the leaf surface and whether the hydrophilic conidia of mildew mycelium increase hydrophilicity. 


\section{Materials and Methods}

\subsection{The Research Area and Sampling}

The subject of analysis were the leaves of common oak (Quercus robur L.). Samples were collected in the forest of Niepołomice Forest District (50.043310, 20.376773) and in Krakow city (50.064338, 19.943621). The average daily annual temperature for the region is $8.7^{\circ} \mathrm{C}$, while the average annual rainfall is $671 \mathrm{~mm}$.

Samples were collected in spring (May) and in autumn (September). In each location and in each season, 10 healthy oak branches and 10 branches with various degrees of powdery mildew infection were sampled. Each branch was from a different tree, and the trees were around 30-40 years old. In May and September, the same trees were taken. In total, 120 samples (branches) were collected: 60 in the forest and 60 in the urban area.

Branches with a length of about $1 \mathrm{~m}$ were collected with pruning shears, in the middle of the height of the crown, on the north side of a tree to maintain repeatability. Each branch was transported separately. For the period of transport, the ends of the branches were protected with paraffin wax.

The experiment was carried out immediately after transport to the laboratory. The entire research process was repeated between 10 and 20 May and between 10 and 20 September.

\subsection{Analyses of the Leaf Surface Condition}

From the transported branches, random samples of leaves were picked for analysis with an electron microscope. The JEOL JSM5410 scanning electron microscope (SEM), (JEOL Ltd, Tokyo, Japan) was used.

Fragments of the leaves were fixed and then sprayed with gold. A series of photos in various ranges of magnification was made of such samples. The photos were used for additional discussion on the influence of the leaf surface condition.

The collected leaves were analyzed by gas chromatography to determine the content of major high-saturated aromatic hydrocarbons. Every leaf was flushed twice with $50 \mathrm{~mL}$ of hexane, then the hexane was filtered through a laboratory paper filter and evaporated to dryness. The mass of the dry residue and dry powder (on the filter) was measured. Dry samples were dissolved in acetonitrile (1 mL each), sonicated for $30 \mathrm{~min}$, filtered and analyzed using HPLC. The Agilent Technologies 1260 system was equipped with a fluorescence detector and an Agilent Technologies Eclipse XDB-C18 $5 \mu \mathrm{m}, 4.6 \times 150 \mathrm{~mm}$ HPLC column. The mobile phases were water (A) and acetonitrile (B) at a flow rate of $1 \mathrm{~mL} / \mathrm{min}$. The sample injection volume was $5 \mu \mathrm{L}$. Compounds were eluted using the following gradient: $0-5 \mathrm{~min}$ 20:80 A:B $\rightarrow 13: 87 \mathrm{~A}: \mathrm{B} ; 5-7.5 \mathrm{~min}$ holding at 13:87 A:B; and 7.5-15 min 13:87 A:B $\rightarrow 0: 100$ A:B. Ten-point calibration curves were prepared for the following compounds: phenanthrene, naphtalene, pyrene, chrysene, benzo[a]pyrene, acenaphthylene, anthracene and fluoranthene. Since these compounds do not occur in nature, their total sum (SUM.PAH) was analyzed separately in the leaves collected in the city $(\mathrm{U})$ and in the forest $(\mathrm{F})$. These compounds were chosen because of their high content in industrial pollutants.

Leaves from the branches intended for an analysis of the effect of oak powdery mildew were scanned and the percentage of cover with the infection was determined using the SigmaScan v5 software (Gambit, Krakow, Poland).

\subsection{Measurement of Contact Angles and Determination of Wettability}

Simulated spraying was carried out at $21^{\circ} \mathrm{C}\left(+/-1{ }^{\circ} \mathrm{C}\right)$. The temperature of the environment and water is very important for water density and the adherence of droplets, and that is why it was important to maintain constant conditions in the laboratory [22]. Using a manual micropipette (CLINIPET+ , PZ HTL S.A, Warsaw, Poland) with $0.5 \mathrm{~mm}$ inner needle diameter and a volume range of $0.5-10 \mu \mathrm{L}$, drops of $0.5 \mu \mathrm{L}$ of distilled water were deposited. Outdropping (depositing of water) was 
continued until 10 drops were obtained in each analyzed case. The equipment used was the Canon Eos 450D camera (Canon, Tokyo, Japan) with the EF $100 \mathrm{~mm} f / 2.8$ Macro USM lens.

In the SigmaScan v5 software, the droplet inclination angle measurements were performed based on the photographs. The internal contact angle (Ang) between the droplet and the leaf was considered [21]. Wettability was determined based on the droplet inclination angles using the classification proposed by Aryal and Neuner [28], where properties ranging from superhydrophilic, through well wettable and hardly wettable, to superhydrophobic are attributed to corresponding droplet ranges. A contact angle of up to $40^{\circ}$ was considered as superhydrophilic and those above $150^{\circ}$ as superhydrophobic. Other contact angles are: $40^{\circ}-90^{\circ}$, highly wettable; $90^{\circ}-110^{\circ}$, wettable; $110^{\circ}-130^{\circ}$, non-wettable; and $130^{\circ}-150^{\circ}$, highly non-wettable.

\subsection{Measurement of the Canopy Water Storage Capacity}

Determination of wettability was supplemented by determination of the quantitative possibilities of retention of water from simulated rainfall, i.e., the canopy water storage capacity (S). The whole experiment was performed indoors in the absence of wind, under the conditions of controlled humidity $(48 \%)$ and at the temperature of $21^{\circ} \mathrm{C}$. Rain simulation was performed on a $30-45 \mathrm{~cm}$ fragment of a harvested branch. The branches were weighed in a fresh state to obtain biomass (BM). Rainfall was simulated by spraying with a constant dose of water on a branch suspended on a fishing line with a weight attached. Weighing was repeated after spraying. The amount of water retained was calculated from the difference between the wet and the dry branch (A). The setting of branches during spraying was similar to their natural orientation on a tree [39]. A fixed dose of water, equal to $\mathrm{P}=100.0 \mathrm{~g}$, was assumed. Water in specified doses fell from a scaled container over the twig, and the intensity was constant throughout the rain duration, which provided comparable results for each case. Water spraying was made from a constant distance of $0.4 \mathrm{~m}$. The canopy water storage capacity per biomass was calculated according to the formula used by Garcia-Estringana [1]: S = A/BM g water/g biomass. Biomass is a good predictor for calculating the canopy water storage capacity.

The simulated spraying and setting droplets on leaves was done using distilled water (Poch SA). The precipitation simulation method was described in the works of Klamerus-Iwan and Błońska [22] and Klamerus-Iwan et al. [40].

\subsection{Statistical Analyses}

The quantitative variables analyzed did not have a normal distribution, therefore the comparison in two groups was performed using the Mann-Whitney test. Correlations between them were analyzed using the Spearman rank correlation coefficient. The strength of dependencies was interpreted according to the following pattern: $|\mathrm{r}| \geq 0.9$, very strong dependency; $0.7 \leq|\mathrm{r}|<0.9$, strong dependency; $0.5 \leq|\mathrm{r}|<0.7$, moderately strong dependency; $0.3 \leq|\mathrm{r}|<0.5$, weak dependency; and $|\mathrm{r}|<0.3$, very weak (negligible) dependency. The interpretation pattern follows Hinkle et al. [41].

A multifactor analysis of the independent influence of many variables on the quantitative variable was performed by applying linear regression. The results are presented in the form of values of regression model parameters with a 95\% confidence interval. The strength of the influence of individual variables was assessed using standardized parameters. The normality of distribution of the variables was examined using the Shapiro-Wilk test. The significance level of 0.05 was adopted in the analysis. Therefore, all $p$ values below 0.05 were interpreted as indicating significant dependencies.

The analysis was carried out using the $\mathrm{R}$ software, version 3.4.4. $\mathrm{R}$ Core Team ( $\mathrm{R}$ Foundation for Statistical Computing, Vienna, Austria) [42].

\section{Results}

The canopy water storage capacity on 120 branches of common oak was tested in the experiment. Table 1 shows the average values of $S$. Each variant of surface variability was analyzed on 10 branches. Analyzing the presented results, we can see that all canopy water storage capacities are higher for 
branches taken in urban forest. In terms of the month in which samples were taken, the higher S was recorded in September for both locations. The effect of leaf cover of mildew mycelium is also pronounced. We observe that, regardless of the location and month of sampling, higher coverage with powdery mildew leads to higher S.

Table 1. Variability in the water storage capacity of common oak.

\begin{tabular}{|c|c|c|c|c|c|c|c|c|c|c|c|c|}
\hline \multirow{5}{*}{$\begin{array}{c}\text { Species } \\
\text { Location } \\
\text { Month } \\
\text { Mildew }(\%) \\
\text { m_S (g/g) }\end{array}$} & \multicolumn{12}{|c|}{ Common Oak } \\
\hline & \multicolumn{6}{|c|}{ Urban forest } & \multicolumn{6}{|c|}{ Natural forest } \\
\hline & \multicolumn{3}{|c|}{ May } & \multicolumn{3}{|c|}{ September } & \multicolumn{3}{|c|}{ May } & \multicolumn{3}{|c|}{ September } \\
\hline & 0 & 20 & 80 & 0 & 20 & 80 & 0 & 20 & 80 & 0 & 20 & 80 \\
\hline & 0.915 & 3.380 & 14.45 & 15.86 & 21.00 & 35.05 & 0.89 & 3.21 & 14.19 & 11.21 & 15.23 & 25.02 \\
\hline
\end{tabular}

The average value range for $\mathrm{S}$ is from $0.89 \mathrm{~g} / \mathrm{g}$ for branches without powdery mildew, taken in May in the natural forest to $35.05 \mathrm{~g} / \mathrm{g}$ for branches taken in September in the urban forest with mildew infection. To determine the influence of all factors assumed in the research hypotheses, analyses of individual factors were made and a multifactor analysis was carried out.

\subsection{The Influence of Individual Factors on Canopy Water Storage Capacity (S)}

\subsubsection{The Influence of the Leaf Sample Location on $S$}

$S$ did not have the normal distribution in the analyzed groups ( $p$ in the Shapiro-Wilk test below 0.05); therefore, the analysis was carried out using the Mann-Whitney test, and the diagram presents medians, quartiles and ranges of values (Figure 1). The $p$ value is greater than 0.05 , therefore $S$ does not depend on the location if we examine the individual impact of this factor (Table 2).

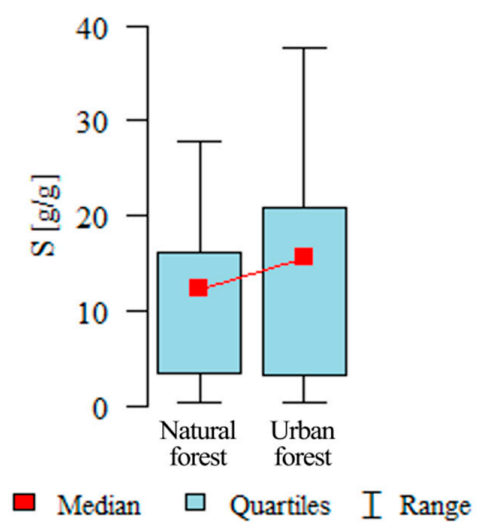

Figure 1. Medians, quartiles and ranges of values for $S$ relative to location; $S$, canopy water storage capacity.

Table 2. Analysis of the impact of location on $\mathrm{S}(\mathrm{g} / \mathrm{g})$.

\begin{tabular}{cccccccccc}
\hline Type of forest & $\mathbf{N}$ & Mean & SD & \multicolumn{1}{c}{ MedianMin } & Max & Q1 & Q3 & $p$ \\
\hline Natural forest & 60 & 11.62 & 8.19 & 12.35 & 0.5 & 27.8 & 3.48 & 16.22 & 0.098 \\
Urban forest & 60 & 15.11 & 11.59 & 15.65 & 0.5 & 37.7 & 3.35 & 20.95 & \\
\hline
\end{tabular}

S, canopy water storage capacity; $p$, Mann-Whitney test.

The location in which the samples were collected is related to the amount of pollution accumulated on their surface (Figure 1). The results of the total amount of leaf pollution (SUM.PAH) with polycyclic aromatic hydrocarbons indicate that in May the pollution was on a very similar level of $913.9 \mu \mathrm{g} / \mathrm{kg}$ in the city and $894.5 \mu \mathrm{g} / \mathrm{kg}$ in the forest. In September, the amount of PAH in leaves sampled in the city reached $1773.1 \mu \mathrm{g} / \mathrm{kg}$ while in the forest was $1208.2 \mu \mathrm{g} / \mathrm{kg}$. 
The values of canopy water storage capacity and wettability of leaves surface referred to changes on the surface of leaves, therefore, it is important to present the image generated by the scanning electron microscope (SEM) (Figures 2 and 3). We can observe contaminated mycelial conidia of powdery mildew (Figure 2).

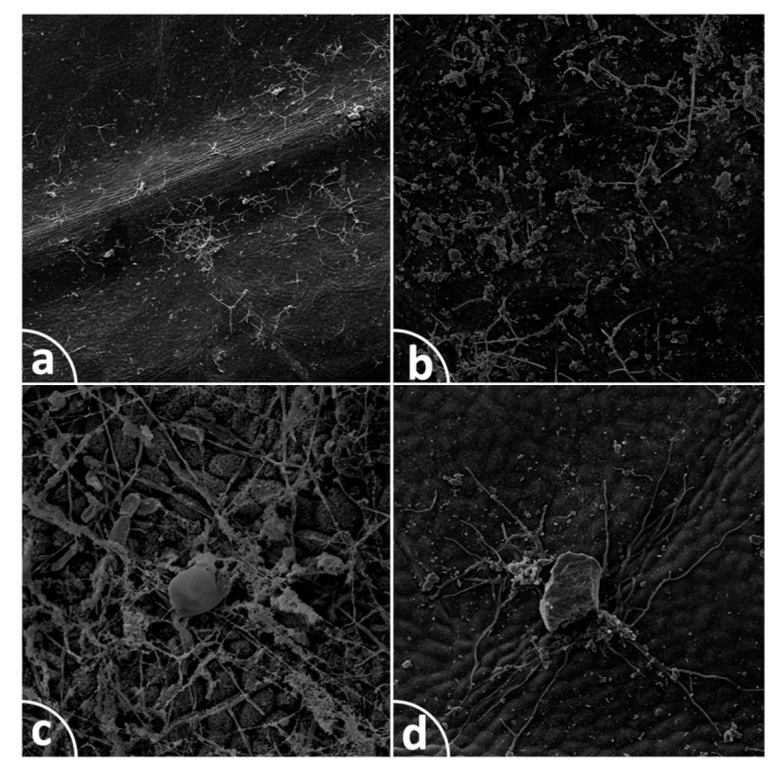

Figure 2. Images of the common oak leaf surface obtained by the scanning electron microscope (SEM): (a) a fragment of the leaf surface with the mycelium (Hyphae), the leaf sampled in May, magnification $\times 50$; (b) the net of oak powdery mildew mycelium with retained pollution, magnification $\times 150$; (c) conidia of oak powdery mildew with retained pollution, magnification $\times 350$; and (d) particulate matter with pollution retained within the oak powdery mildew mycelium, the leaf sampled in September, magnification $\times 200$.

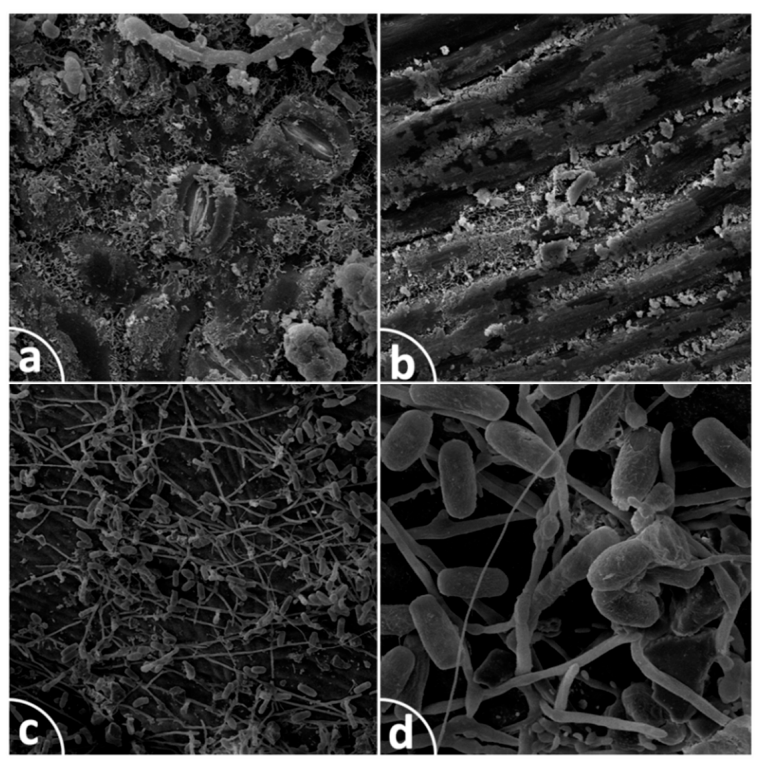

Figure 3. Images of the common oak leaf surface obtained by the scanning electron microscope (SEM): (a) a leaf sampled in September with stomatal apparatuses covered with pollution, magnification $\times 1000$; (b) a leaf sampled in September with leaf surface erosion, magnification $\times 1000$; (c) a leaf sampled in May with the oak powdery mildew mycelium with fresh conidia, magnification $\times 200$; and (d) conidia of Microsphaera alphitoides Griff. et Maubl., magnification $\times 1000$. 


\subsubsection{The Influence of Seasonality on S}

The canopy water storage capacity did not have a normal distribution in the analyzed groups $(p$ in the Shapiro-Wilk test below 0.05); therefore, the analysis was carried out using the Mann-Whitney test, and the diagram presents medians, quartiles and ranges of values (Figure 4). The $p$ value is lower than 0.05 , which means that $S$ depends on the month in which the samples were collected. In September, the canopy water storage capacity is higher (Table 3).

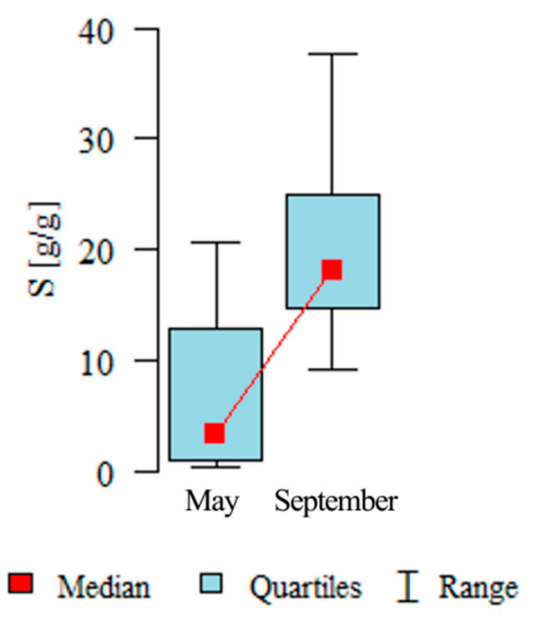

Figure 4. Dependence of canopy water storage capacity from the month of sampling; $V$, samples taken in May; IX, samples taken in September.

Table 3. Analysis of the influence of the leaf sampling time on $\mathrm{S}(\mathrm{g} / \mathrm{g})$.

\begin{tabular}{cccccccccc}
\hline Month & N & Mean & SD & MedianMin & Max & Q1 & Q3 & $p$ \\
\hline May & 60 & 6.17 & 6.13 & 3.4 & 0.5 & 20.6 & 1.04 & 12.8 & $<0.001$ \\
September & 60 & 20.56 & 8.04 & 18.15 & 9.3 & 37.7 & 14.73 & 24.88 & \\
\hline \multicolumn{8}{c}{ S, canopy water storage capacity;, , Mann-Whitney test. }
\end{tabular}

In images from the scanning electron microscope, we can observe contaminated stomata (Figure 3a) and the erosion of wax crystals (Figure 3b).

\subsubsection{The Influence of Mildew on S}

$S$ did not have the normal distribution in the analyzed groups ( $p$ in the Shapiro-Wilk test below 0.05); therefore, the analysis was based on the Spearman correlation coefficient. The correlation coefficient between $S$ and mildew is statistically significant $(p<0.001)$, which means that these two characteristics depend significantly on each other. The correlation coefficient is at the level of 0.628. This dependency is positive, which means that the higher the mildew, the higher the $S$ (Figure 5).

The way drops adhere to a leaf with mildew infection is shown in Figure 6.

In images from the scanning electron microscope, we can observe oak powdery mildew mycelium with fresh conidia (Figure 3). 


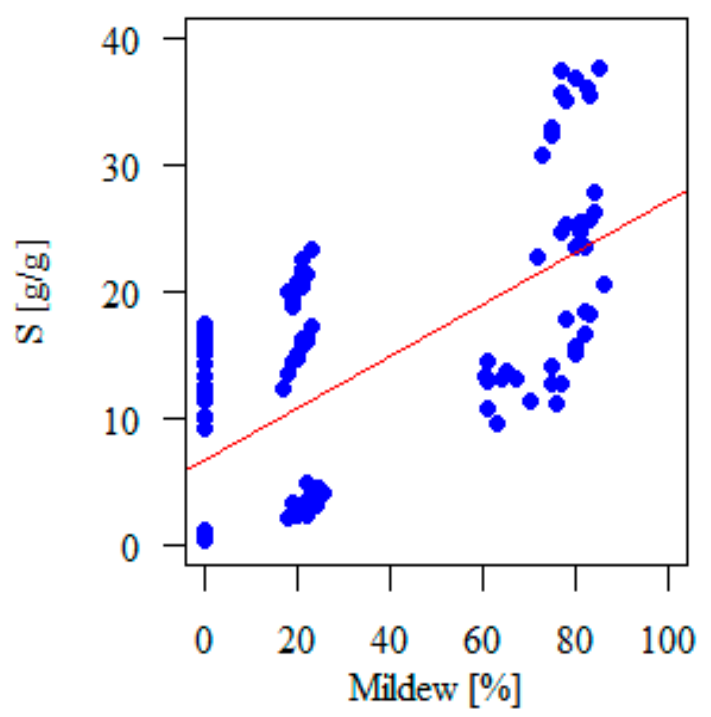

Figure 5. A diagram of dependency between $S$ (canopy water storage capacity) and mildew (Microsphaera alphitoides Griff. et Maubl).

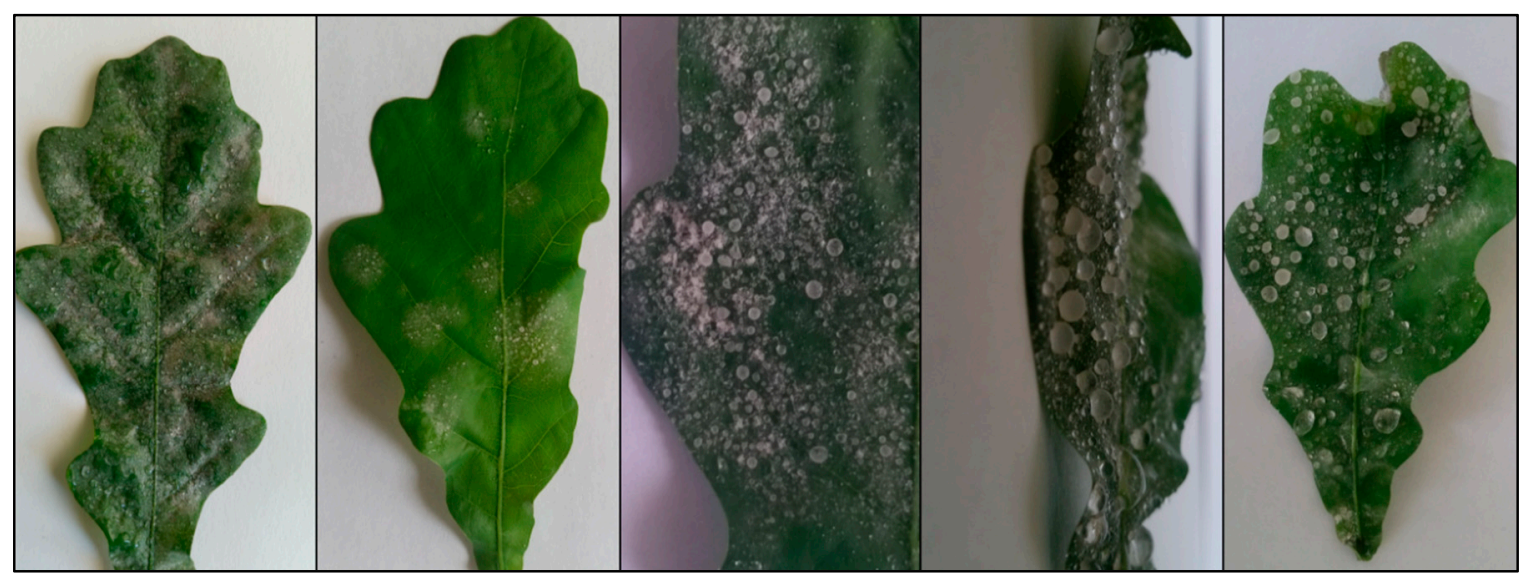

Figure 6. Photographs of raindrops retained on common oak leaves with different degrees of infection with oak powdery mildew.

\subsection{Multiple Factor Analysis of Factors Affecting $S$}

The linear regression model showed that all analyzed factors, i.e., the date of sampling, location, the number of mildew infections, and the contact angle of raindrops, are independent predictors $S$ $(\mathrm{g} / \mathrm{g})(p<0.05)$. The mildew cover growing by each additional percent increases $\mathrm{S}$ by an average of $0.174 \mathrm{~g} / \mathrm{g}$. An increase of the angle of inclination (Ang) by each additional degree reduces $\mathrm{S}$ by an average of $0.072 \mathrm{~g} / \mathrm{g}$. In comparison with May, in September, $\mathrm{S}$ rises by an average of $7176 \mathrm{~g} / \mathrm{g}$. In comparison with the forest, in the city, $\mathrm{S}$ increases by an average of $3.115 \mathrm{~g} / \mathrm{g}$ (Table 4). The $R^{2}$ coefficient was $94.47 \%$ for this model. 
Table 4. Multiple factor analysis of factors affecting S.

\begin{tabular}{|c|c|c|c|c|c|c|}
\hline \multirow{2}{*}{\multicolumn{2}{|c|}{$\begin{array}{c}\text { Variable } \\
\text { (absolute term) }\end{array}$}} & \multirow{2}{*}{$\begin{array}{l}\text { Standardized } \\
\text { Parameter }(\beta)\end{array}$} & \multirow{2}{*}{$\begin{array}{c}\begin{array}{c}\text { Regression } \\
\text { Parameter B }\end{array} \\
9.304\end{array}$} & \multicolumn{2}{|c|}{$95 \%$ CI } & \multirow{2}{*}{$\begin{array}{c}p \\
0.062\end{array}$} \\
\hline & & & & -0.494 & 19.101 & \\
\hline \multirow{2}{*}{\multicolumn{2}{|c|}{$\begin{array}{c}\text { Mildew }(\%) \\
\text { Ang }\left({ }^{\circ}\right)\end{array}$}} & 0.555 & 0.174 & 0.147 & 0.2 & $<0.001$ \\
\hline & & -0.354 & -0.072 & -0.136 & -0.008 & 0.027 \\
\hline \multirow{2}{*}{ Term } & May & & & & & \\
\hline & September & 0.355 & 1.057 & 13.295 & 0.022 & \\
\hline \multirow{2}{*}{ Location } & Natural forest & & & & & \\
\hline & Urban forest & 0.154 & 2.227 & 4.002 & $<0.001$ & \\
\hline
\end{tabular}

Standardized parameters $(\beta)$ indicate the strength of the influence of individual variables on $\mathrm{S}(\mathrm{g} / \mathrm{g})$. The strongest influence belongs to mildew, then to an almost equal degree to the month and the contact angle, while location has the weakest influence. A decreasing angle of inclination of the droplet to the leaf denotes increasing wettability, which means an increase in the canopy water storage capacity.

\subsection{The Relationship between the Contact Angle and the Canopy Water Storage Capacity}

The correlation coefficient between $S$ and the contact angle is statistically significant $(p<0.0001)$; therefore, these two characteristics depend significantly on each other. The Spearman correlation coefficient is -0.91 and the strength of the dependency is very high. This dependency is negative, which means that, the larger the contact angle, the lower the $S$ (Figure 7).

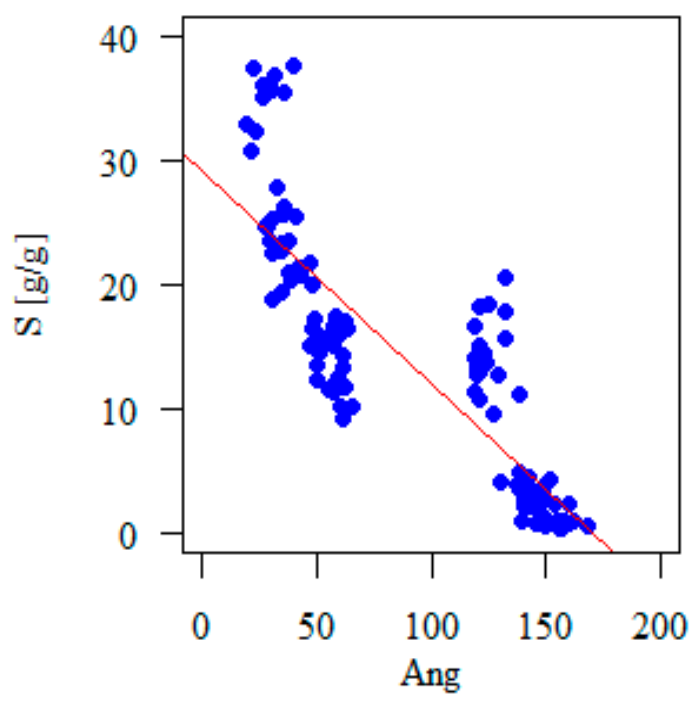

Figure 7. Dependency between canopy water storage capacity and contact angle; S, canopy water storage capacity; Ang, contact angle $\left(^{\circ}\right)$.

The analyzed factors which affect $\mathrm{S}$ also have an influence on the contact angle. The influence of the location in which the samples were collected, of the date of sampling and of the degree of leaf cover with oak powdery mildew on the contact angle is presented in Table 5. For the purpose of clarity of presentation of the degree of oak powdery mildew infection, the areas covered by white coating were grouped in the following ranges: healthy or $0 \%$ cover, coating on up to $20 \%$ of the leaf surface, and coating on up to $80 \%$ of the leaf surface. A decreasing angle of inclination (Ang) of the droplet to the leaf testifies to growing wettability. 
Table 5. Juxtaposition of the contact angle and the class of wettability in the analyzed plant material.

\begin{tabular}{|c|c|c|c|c|c|}
\hline Species & Location & Term & Mildew (\%) & Ang $\left(^{\circ}\right)$ & Wettability \\
\hline \multirow{12}{*}{ OAK } & \multirow{6}{*}{ Urban forest } & \multirow{3}{*}{ May } & 0 & 152.42 & superhydrophobic \\
\hline & & & $>20$ & 143.54 & highly non-wettable \\
\hline & & & $>80$ & 126.02 & non-wettable \\
\hline & & \multirow{3}{*}{ September } & 0 & 59.47 & highly wettable \\
\hline & & & $>20$ & 38.83 & superhydrophilic \\
\hline & & & $>80$ & 27.84 & superhydrophilic \\
\hline & \multirow{6}{*}{ Natural forest } & \multirow{3}{*}{ May } & 0 & 153.56 & superhydrophobic \\
\hline & & & $>20$ & 143.02 & highly non-wettable \\
\hline & & & $>80$ & 122.48 & non-wettable \\
\hline & & \multirow{3}{*}{ September } & 0 & 60.16 & highly wettable \\
\hline & & & $>20$ & 50.33 & highly wettable \\
\hline & & & $>80$ & 33.38 & superhydrophilic \\
\hline
\end{tabular}

The analyzed factors which affect $\mathrm{S}$ also have an influence on the contact angle. The influence of the location in which the samples were collected, of the date of sampling and of the degree of leaf cover with oak powdery mildew on the contact angle is presented in Table 5. For the purpose of clarity of presentation of the degree of oak powdery mildew infection, the areas covered by white coating were grouped in the following ranges: healthy or $0 \%$ cover, coating on up to $20 \%$ of the leaf surface, and coating on up to $80 \%$ of the leaf surface. A decreasing angle of inclination (Ang) of the droplet to the leaf testifies to growing wettability.

\section{Discussion}

This study demonstrates that $\mathrm{S}(\mathrm{g} / \mathrm{g})$ strongly depends on multiple spatiotemporal factors for a single species, including: phenology, setting, degree of mildew infection and hydrophobicity (Table 4). In the univariate analysis, the location from which the samples were obtained turned out to be irrelevant. This means that the location has an impact on $\mathrm{S}$ but some factors related to the location itself reduce that impact. Undoubtedly, these factors include the degree of leaf cover with pollution and the type of pollution [43] as well as higher temperatures in the city, which affects individual characteristics [44]. The level of leaf contamination with aromatic hydrocarbons is very similar for both locations in May while in September the leaf PAH content was much lower in the natural forest, $1200 \mathrm{ug} / \mathrm{kg}$, compared to the urban forest, $1773.1 \mathrm{ug} / \mathrm{kg}$. The canopy water storage capacity for healthy leaves, i.e., ones without oak powdery mildew, sampled in May, both in the city and in the forest, amounts to an average of $1 \%$ of the total simulated precipitation. The angles of inclination of raindrops to the leaf surface are also similar: $153^{\circ}$. This indicates that a tree's setting (in an urban or natural forest) does not directly influence S; rather, it influences other S-related variables (leaf hydrophobicity, mildew infection and/or PAH content).

The univariate analysis confirms a very strong impact of the month in which the samples were collected. An increase was observed in mean S, from $6.2 \%$ of total simulated rainfall in May to $20.6 \%$ in September; therefore, the age of a leaf and its phenological condition must not be neglected in ecohydrological research. A significant influence of the age of a leaf can also be seen in the angles of inclination of a raindrop to a leaf. An analysis of just the healthy leaves in May revealed the average contact angle of $153^{\circ}$ while in the samples collected in September the angle was $30^{\circ}$. This indicates a change in wettability from superhydrophobic to superhydrophilic [28]. This conclusion confirms the previously observed interdependence of season, wettability and S [40], and shows that seasonality, even under the influence of pollution or leaf diseases, plays a decisive role in the amount of water that can be stored in the canopy. On young and healthy leaves sampled in May, it was difficult to analyze the droplet inclination angle because the surface of those leaves was very strongly hydrophobic and the drops quickly drained from the surface (Figure 6, Video S1). 
A novelty in the present study is the linking of the canopy water storage capacity with oak mildew pathogens. The white mycelial coating increased S (Figure 6). For samples collected in the forest in May, for the $0 \%$ powdery mildew cover, $S$ was on average $1 \%$ of the total rainfall; for the powdery mildew cover of up to $20 \%$, S was up to $3 \%$; and, for the cover of up to $80 \%$, oak branches retained even up to $15 \%$ of all precipitation.

On young leaves, rainwater droplets only to adhered to the leaf surface in places covered by mycelium (Figure 6). In September, along with the analogous increase in mildew cover on leaves, the $S$ values grew from $11 \%$ to $25 \%$. Therefore, we can see a distinct influence of leaf age, i.e., the month when a sample was collected for analysis [45].

Favorable conditions for the formation of Microsphaera alphitoides conidia are sunny and warm springs and summers, while their germination requires moisture in the form of drops [34,35]. By retaining more water from precipitation, the pathogen ensures favorable conditions for the development of mycelium.

A larger amount of precipitation retained by leaves infected with powdery mildew results from a change in surface conditions, becoming "rougher" compared to an uninfected leaf; and the surface condition as a material feature has a large impact on the amount of water retained not only by the plant material. Leaves with an 80\% powdery mildew infection, sampled in the city in September, stopped an average of $35 \%$ of rainfall while those sampled in the forest retained $25 \%$ of rainfall. The corresponding inclination angle was $35.5^{\circ}$ and $23.6^{\circ}$, respectively. This indicates that air pollutants may play a significant role in advancing oak powdery mildew infection. An additional analysis of photographs from the scanning electron microscope (SEM) showed that the texture of the oak mildew mycelium is responsible for a larger amount of pollution being caught by the mycelium conidia (Figure 2). A smaller angle of inclination of raindrops to the leaf surface indicates greater adhesiveness. It may therefore be concluded that powdery mildew occurring in polluted areas may intensify the impact of pollution on the $\mathrm{S}$ and wettability of the plant material. Aromatic hydrocarbons themselves are hydrophobic and difficult to wash in water, but the experiments conducted reveal that a growing amount of pollution does not reduce the amount of water retained on the leaves. In addition, the SEM pictures (Figure 3) show that the contaminants clog stomata, which should also affect a reduction of $\mathrm{S}$; however, the experiment indicates the opposite relationship. This may be explained by the surface texture of leaves with high PAH content. Small particles sticking to the surface of the leaf increase the adhesion of droplets, which increases $S$ and decreases the angle of droplets as a result of growing pollution, i.e., wettability increases (Figure 2). Using leaf surface images is a very useful tool for diagnosing mildew coverage $[46,47]$.

Although periods of high leaf wettability were observed in this study for mildew-covered leaves, the surface of healthy leaves from the same trees were superhydrophobic (Figure 6, Video S1).). In this case, it is said that the solid is absolutely unwettable (superhydrophobic) $[48,49]$.

An analysis of factors that affect the $S$ and wettability is of increasing interest to ecohydrologists $[8,29,50-53]$. However, the mechanism of the adherence of water to the plant material is not yet fully understood $[8,9,54]$. Nevertheless, the amounts of water which are retained in the canopy of trees and which will not reach the forest floor cannot be disregarded either in research of catchment hydrology or in an analysis of physical characteristics of the plant material [55-57].

The canopy water storage capacity and the amount of water transferred to the subcrown zone is particularly important in the restoration of desert ecosystems for xerophyticshurbs [58]. Determination of the size of the $S$ is significant both for catchment hydrology [59], when modeling losses for interception [60], and for determination of the physical characteristics of the plant material.

\section{Conclusions}

The present study shows how the process of leaf aging in urban versus natural forest settings with varying degrees of mildew infection affects canopy water storage capacity (S). We obtain important information that factors conditioning the ecohydrological properties of leaves are difficult to consider 
individually. Leaf age, in combination with the degree of fungal infection and polycyclic aromatic hydrocarbon $(\mathrm{PAH})$ content, can mutually intensify or reduce wettability, thereby changing the rainfall retention capabilities of tree crowns.

The present research reveals that, along with age and the growing degree of pollution, common oak exhibits a higher canopy water storage capacity and greater wettability. The oak leaves collected in May are superhydrophobic, as visually apparent in the supplemental video. A novelty in this research is the fact that the degree of leaf cover with the pathogen that builds a hydrophilic mycelium on the leaf, namely oak powdery mildew, also increases canopy water storage capacity and wettability. Moreover, an analysis of scanning electron microscope images shows that the conidia of the fungus may lead to the capture of pollution from the air, by which oak is able to retain even more water.

Supplementary Materials: The following are available online at http:/ /www.mdpi.com/2073-4441/10/6/695/s1, Video S1: Superhydrophobicity of common oak leaves collected in May.

Author Contributions: A.K.-I. conceived and designed the experiments; A.K.-I. performed the experiments; A.K.-I. analyzed the data; A.K.-I. and W.W. contributed reagents/materials/analysis tools; and A.K.-I. and W.W. wrote the paper.

Funding: This research was financed by the Ministry of Science and Higher Education of the Republic of Poland. This research was also financially supported by subsidies for young research scientists at University of Agriculture in Krakow: BM-4462/ZIL/2017.

Acknowledgments: The authors would like to thank anonymous reviewers for the thorough assessment of this paper and for many valuable and helpful suggestions.

Conflicts of Interest: The authors declare no conflict of interest.

\section{References}

1. Garcia-Estringana, P.; Alonso-Blázquez, N.; Alegre, J. Water storage capacity, stemflow and water funneling in Mediterranean shrubs. J. Hydrol. 2010, 389, 363-372. [CrossRef]

2. Gash, J.H.C.; Loyd, C.R.; Lachaud, G. Estimating sparse forest rainfall interception with an analytical model. J. Hydrol. 1995, 170, 79-86. [CrossRef]

3. Keim, R.F.; Skaugset, A.E.; Weiler, M. Storage of water on vegetation under simulated rainfall of varying intensity. Adv. Water Resour. 2006, 29, 974-986. [CrossRef]

4. Crockford, R.H.; Richardson, D.P. Partitioning of rainfall into throughfall, stemflow and interception: Effect of forest type, ground cover and climate. Hydrol. Process. 2000, 14, 2903-2920. [CrossRef]

5. Leelamanie, D.A.L.; Karube, J.; Yoshida, A. Characterizing water repellency indices: Contact angle and water drop penetration time of hydrophobized sand. Soil Sci. Plant Nutr. 2008, 54, 179-187. [CrossRef]

6. Yu, Y.; Shao, H.; He, Z.; Tang, C.; Yang, J.; Li, Y.; Wang, C.; Li, X.; Shuai, M.; Mei, J. Patternable Poly(chloro-p-xylylene) Film with Tunable Surface Wettability Prepared by Temperature and Humidity Treatment on a Polydimethylsiloxane. Silica Coating. Materials 2018, 11, 486. [CrossRef] [PubMed]

7. Tranquada, G.C.; Erb, U. Morphological Development and Environmental Degradation of Superhydrophobic Aspen and Black Locust Leaf Surfaces. Ecohydrology 2014, 7, 1421-1436. [CrossRef]

8. Rosado, B.H.P.; Holder, C.D. The significance of leaf water repellency in ecohydrological research: A review. Ecohydrology 2013, 6, 150-161. [CrossRef]

9. Fernández, V.; Eichert, T. Uptake of hydrophilic solutes through plant leaves current state of knowledge and perspectives of foliar fertilization. Crit. Rev. Plant Sci. 2009, 28, 36-68. [CrossRef]

10. Sioma, A.; Socha, J.; Klamerus-Iwan, A. A New Method for Characterizing Bark Microrelief Using 3D Vision Systems. Forests 2018, 9, 30. [CrossRef]

11. Holder, C.D.; Gibbes, C. Influence of leaf and canopy characteristics on rainfall interception and urban hydrology. Hydrol. Sci. J. 2016, 62, 182-190. [CrossRef]

12. Nanko, K.; Hotta, N.; Suzuki, M. Evaluating the influence of canopy species and meteorological factors on throughfall drop size distribution. J. Hydrol. 2006, 329, 422-431. [CrossRef]

13. Klaassen, W.; Lankreijer, H.J.M.; Veen, A.W.L. Rainfall interception near a forest edge. J. Hydrol. 1996, 185, 349-361. [CrossRef] 
14. Liu, S. Evaluation of the Liu model for predicting rainfall interception in forests world-wide. Hydrol. Process. 2001, 15, 2341-2360. [CrossRef]

15. Keim, R.F.; Skaugset, A.E.; Link, T.E.; Iroumé, A. A stochastic model of throughfall for extreme events. Hydrol. Earth Syst. Sci. 2004, 8, 23-34. [CrossRef]

16. Friesen, J.; Lundquist, J.; Van Stan, J.T. Evolution of forest precipitation water storage measurement methods. Hydrol. Process. 2015, 29, 2504-2520. [CrossRef]

17. Allen, S.T.; Brooks, J.R.; Keim, R.F.; Bond, B.J.; McDonnell, J.J. The role of pre-event canopy storage in throughfall and stemflow by using isotopic tracers. Ecohydrology 2014, 7, 858-868. [CrossRef]

18. Bryant, M.L.; Bhat, S.; Jacobs, J.M. Measurements and modeling of throughfall variability for five forest communities in the southeastern US. J. Hydrol. 2005, 312, 95-108. [CrossRef]

19. Neinhuis, C.; Barthlott, W. Characterization and distribution of water-repellent, self-cleaning plant surfaces. Ann. Bot. 1997, 79, 667-677. [CrossRef]

20. Holder, C.D. Effects of Leaf Hydrophobicity and Water Droplet Retention on Canopy Storage Capacity. Ecohydrology 2013, 6, 483-490. [CrossRef]

21. Koch, K.; Barthlott, W. Superhydrophobic and superhydrophilic plant surfaces: An inspiration for biomimetic materials. Philos. Trans. R. Soc. A 2009, 367, 1487-1509. [CrossRef] [PubMed]

22. Klamerus-Iwan, A.; Błońska, E. Canopy storage capacity and wettability of leaves and needles: The effect of water temperature changes. J. Hydrol. 2018. [CrossRef]

23. De Jong, S.M.; Jetten, V.G. Estimating spatial patterns of rainfall interception from remotely sensed vegetation indices and spectral mixture analysis. Int. J. Geogr. Inf. Sci. 2007, 21, 529-545. [CrossRef]

24. Sæbø, A.; Popek, R.; Nawrot, B.; Hanslin, H.M.; Gawronska, H.; Gawronski, S.W. Plant species differences in particulate matter accumulation on leaf surfaces. Sci. Total Environ. 2012, 427-428, 347-354. [CrossRef] [PubMed]

25. Ugolini, F.; Tognetti, R.; Raschi, A.; Bacci, L. Quercus ilex L. as bioaccumulator for heavy metals in urban areas: Effectiveness of leaf washing with distilled water and considerations on the trees distance from traffic. Urban For. Urban Green 2013, 12, 576-584. [CrossRef]

26. World Health Organization. WHO Air Quality Guidelines for Particulate Matter, Ozone, Nitrogen Dioxide and Sulfur Dioxidee Global; Summary of Risk Assessment; World Health Organization: Geneva, Switzerland, 2009.

27. Van Stan, J.T.; Levia, D.F.; Jenkins, R.B. Forest Canopy Interception Loss Across Temporal Scales: Implications for Urban Greening Initiatives. Prof. Geogr. 2015, 67, 41-51. [CrossRef]

28. Aryal, B.; Neuner, G. Leaf wettability decreases along an extreme altitudinal gradient. Oecologia 2010, 162, 1-9. [CrossRef] [PubMed]

29. Shujie, W.; Hujun, W.; Chun, L.; Xiangmei, Z.; Hui, H.; Yajun, Z. Adsorption characteristics of droplets applied on non-smooth leaf surface of typical crops. Int. J. Agric. Biol. Eng. 2016, 9, 35-41.

30. Gniwotta, F.; Vogg, G.; Gartmann, V.; Carver, T.L.; Riederer, M.; Jetter, R. What do microbes encounter at the plant surface? Chemical composition of pea leaf cuticular waxes. Plant Physiol. 2005, 139, 519-530. [CrossRef] [PubMed]

31. Sikorska, D.; Papierowska, E.; Szatyłowicz, J.; Sikorski, P.; Suprun, K.; Hopkins, R.J. Variation in Leaf Surface Hydrophobicity of Wetland Plants: The Role of Plant Traits in Water Retention. Wetlands 2017, 37, 997-1002. [CrossRef]

32. Bhushan, B.; Jung, Y.C. Natural and biomimetic artificial surfaces for superhydrophobicity, self-cleaning, low adhesion and drag reduction. Prog. Mater. Sci. 2011, 56, 1-108. [CrossRef]

33. Stosch, A.K.; Solga, A.; Steiner, U.; Oerke, C.; Barthlott, W.; Cermann, Z. Efficiency of self-cleaning properties in wheat (Triticumaestivum L.). Appl. Bot. Food Qual. 2007, 81, 49-55.

34. Kiss, L.; Russell, J.; Szentiványi, O.; Xu, X.; Jeffries, P. Biology and biocontrol potential of Ampelomycesmycoparasites, natural antagonists of powdery mildew fungi. Biocontrol Sci. Technol. 2004, 14, 635-651. [CrossRef]

35. Liyanage, K.K.; Khan, S.; Brooks, S.; Mortimer, P.E.; Karunarathna, S.C.; Xu, J.; Hyde, K.D. Taxonomic revision and phylogenetic analyses of rubber powdery mildew fungi. Microb. Pathog. 2017, 105, 185-195. [CrossRef] [PubMed]

36. Staelens, A.; De Schrijver, K.; Verheyen, N.E.C. Rainfall partitioning into throughfall, stemflow, and interception within a single beech (Fagus sylvatica L.) canopy: Influence of foliation, rain event characteristics, and meteorology. Hydrol. Process. 2008, 22, 33-45. [CrossRef] 
37. Gerrits, A.M.J.; Pfister, L.; Savenije, H.H.G. Spatial and temporal variability of canopy and forest floor interception in a beech forest. Hydrol. Process. 2010, 24, 3011-3025. [CrossRef]

38. Sadeghi, S.M.M.; Van Stan, J.T.; Pypker, T.G.; Tamjidi, J.; Friesen, J. Importance of transitional leaf states in canopy rainfall partitioning dynamics. Eur. J. Forest Res. 2018. [CrossRef]

39. Xiao, Q.; McPherson, E. Surface water storage capacity of twenty tree species in Davis, California. J. Environ. Qual. 2016, 45, 188-198. [CrossRef] [PubMed]

40. Klamerus-Iwan, A.; Błońska, E.; Lasota, J.; Waligórski, P.; Kalandyk, A. Seasonal variability of leaf water capacity and wettability under the influence of pollution in different city zones. Atmos. Pollut. Res. 2017. [CrossRef]

41. Hinkle, D.E.; Wiersma, W.; Jurs, S.G. Applied Statistics for the Behavioral Sciences, 5th ed.; Houghton Mifflin: Boston, MA, USA, 2003.

42. R Core Team. R: A Language and Environment for Statistical Computing; R Foundation for Statistical Computing: Vienna, Austria, 2017; Available online: https:/ /www.R-project.org/ (accessed on 1 April 2018).

43. Popek, R.; Gawrońska, H.; Wrochna, M.; Gawroński, S.; Sæbø, A. Particulate matter on foliage of 13 woody species: Deposition on surfaces and phytosta- bilisation in waxes, a 3 year Study. Int. J. Phytoremed. 2012, 15, 245-256. [CrossRef] [PubMed]

44. Kozlowski, T.; Pallardy, S.G. Physiology of Woody Plants; Academic Press: Waltham, MA, USA, 1979; 17p, ISBN 978-0-12-088765-1.

45. Baker, E.A.; Hunt, G.M. Erosion of waxes from leaf surfaces by simulated rain. New Phytol. 1986, 102, 161-173. [CrossRef]

46. Behmann, J.; Acebron, K.; Emin, D.; Bennertz, S.; Matsubara, S.; Thomas, S.; Bohnenkamp, D.; Kuska, M.T.; Jussila, J.; Salo, H.; et al. Specim IQ: Evaluation of a New, Miniaturized Handheld Hyperspectral Camera and Its Application for Plant Phenotyping and Disease Detection. Sensors 2018, 18, 441. [CrossRef] [PubMed]

47. Al-Saddik, H.; Laybros, A.; Billiot, B.; Cointault, F. Using Image Texture and Spectral Reflectance Analysis to Detect Yellowness and Esca in Grapevines at Leaf-Level. Remote Sens. 2018, 10, 618. [CrossRef]

48. Holder, C.D. Leaf water repellency as an adaptation to tropical montane cloud forest environments. Biotropica 2007, 39, 767-770. [CrossRef]

49. Dorr, G.J.; Kempthorne, D.M.; Mayo, L.C.; Forster, W.A.; Zabkiewicz, J.A.; McCue, S.W.; Belward, J.A.; Turner, I.W.; Hanan, J. Towards a model of spray-canopy interactions: Interception, shatter, bounce and retention of droplets on horizontal leaves. Ecol. Model 2014, 290, 94-101. [CrossRef]

50. Deguchi, A.; Hattori, S.; Park, H.T. The influence of seasonal changes in canopy structure on interception loss: Application of the revised Gash model. J. Hydrol. 2006, 318, 80-102. [CrossRef]

51. Šraj, M.; Brilly, M.; Mikoš, M. Rainfall interception by two deciduous Mediterranean forests of contrastingstature in Slovenia. Agric. For. Meteorol. 2008, 148, 121-134. [CrossRef]

52. Toba, T.; Ohta, T. Factors affecting rainfall interception determined by a forest simulator and numerical model. Hydrol. Process. 2008, 22, 2634-2643. [CrossRef]

53. Zabret, K.; Rakovec, J.; Mikoš, M.; Šraj, M. Influence of Raindrop Size Distribution on Throughfall Dynamics under Pine and Birch Trees at the Rainfall Event Level. Atmosphere 2017, 8, 240. [CrossRef]

54. Taylor, P. The wetting of leaf surfaces. Curr. Opin. Colloid Interface Sci. 2011, 16, 326-334. [CrossRef]

55. Martin, C.E.; Von Willert, D.J. Leaf epidermal hydathodes and the ecophysiological consequences of foliar water uptake in species of Crassula from the Namib Desert in southern Africa. Plant Biol. 2000, 2, 229-242. [CrossRef]

56. Pypker, T.G.; Bond, B.J.; Link, T.E.; Marks, D.; Unsworth, M.H. The importance of canopy structure in controlling the interception loss of rainfall: Examples from a young and an old-growth Douglas-fir forest. Agric. Forest Meteorol. 2005, 130, 113-129. [CrossRef]

57. Levia, D.F.; Herwitz, S.R. Interspecific variation of bark water storage capacity of three deciduous tree species in relation to stemflow yield and solute flux to forest soils. CATENA 2005, 64, 117-137. [CrossRef]

58. Wang, X.P.; Zhang, Y.F.; Hu, R.; Pan, Y.X.; Berndtsson, R. Canopy storage capacity of xerophytic shrubs in Northwestern China. J. Hydrol. 2012, 454-455, 152-159. [CrossRef] 
59. Grygoruk, M.; Mirosław-Świątek, D.; Chrzanowska, W.; Ignar, S. How much for water? Economic assessment and mapping of floodplain water storage as a catchment-scale ecosystem service of wetlands. Water 2013, 5, 1760-1779. [CrossRef]

60. Ciężkowski, W.; Berezowski, T.; Kleniewska, M.; Szporak-Wasilewska, S.; Chormański, J. Modelling Wetland Growing Season Rainfall Interception Losses Based on Maximum Canopy Storage Measurements. Water 2018, 10, 41. [CrossRef] 